\title{
Life Insurance Retirement Plans For High Income Individuals
}

Johnny Fryar, Jr., Coastal Carolina University, USA

Meyer Drucker, Coastal Carolina University, USA

\begin{abstract}
This paper examines the advantages and disadvantages of using life insurance retirement plans for high net worth individuals. Though the advent of financial economics and simulations like Monte Carlo have introduced empirical data to financial planning, most advances are invented, developed, and later copied from the practices of leading advisors. These advisors come from several different areas of focus using their expertise to solve the financial problems of their clients. With methodologies coming from estateltax attorneys, CPAs, risk management specialists, registered representatives/advisors, and CFPs the path to personal and intergenerational prosperity is not a clear one. As a result, financial planning has developed as more of an art form than a science. The intent of this paper is to bring a controversial, but in certain cases effective, financial instrument to the discussion of financial planning.
\end{abstract}

Keywords: Financial Planning, Retirement, Life Insurance, Tax Planning

\section{INTRODUCTION}

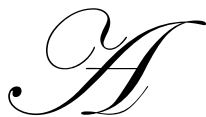

s a precursor to Life Insurance Retirement Plans (LIRPs) one must first have an understanding of some of the tenants of financial planning. With a working knowledge of these tenants, we will look at a select group of clients and demonstrate how their needs can be solved with LIRPs. Once identifying these unique clients and their situations we will examine how LIRPs work and the tax advantages they provide. As with all financial planning tools there are circumstances where these plans are not advantageous and pitfalls that can be avoided with proper planning.

\section{BASIC TENANTS OF FINANCIAL PLANNING}

One of the first and most simple tenants of investing is that of risk vs. reward. If investment A returns $12 \%$ and investment B returns $8 \%$, ceteris paribus, why would you invest in option B? The answer lies in the ability to assume risk. The definition of risk is much different from the point of view of analyst and investor, though they are used as if they have only one meaning. To the analyst, risk is the standard deviation or chance that a return will deviate from the mean or the expected return. To the typical investor risk means one thing - what are the chances I will lose money? Evolving from simple risk and reward, Markowitz developed a theory that combining several investments with an inverse risk/reward profile could lower the risk of an individual's portfolio. ${ }^{1}$

The portfolio takes on its own risk/reward profile that can be plotted on a graph. This graph represents all possible returns on the vertical axis and risks on the horizontal axis. The best result for a certain amount of risk starts in the lower left quadrant and ends progressively upward to the right. This line represents the efficient frontier and the best possible results per increment of risk assumed (Figure 1).

Though these theories do not completely satisfy the client's insatiable goal for unlimited returns with zero risk, they do afford the best possible results given the unpredictability of financial markets. The placement of any portfolio is marked on the graph by a single data point; the portfolio itself can be represented by a pyramid. 
Figure 1: Risk vs. Return Illustration ${ }^{2}$

$1970-2005$

\section{Stocks and Bonds: Risk Versus Return}

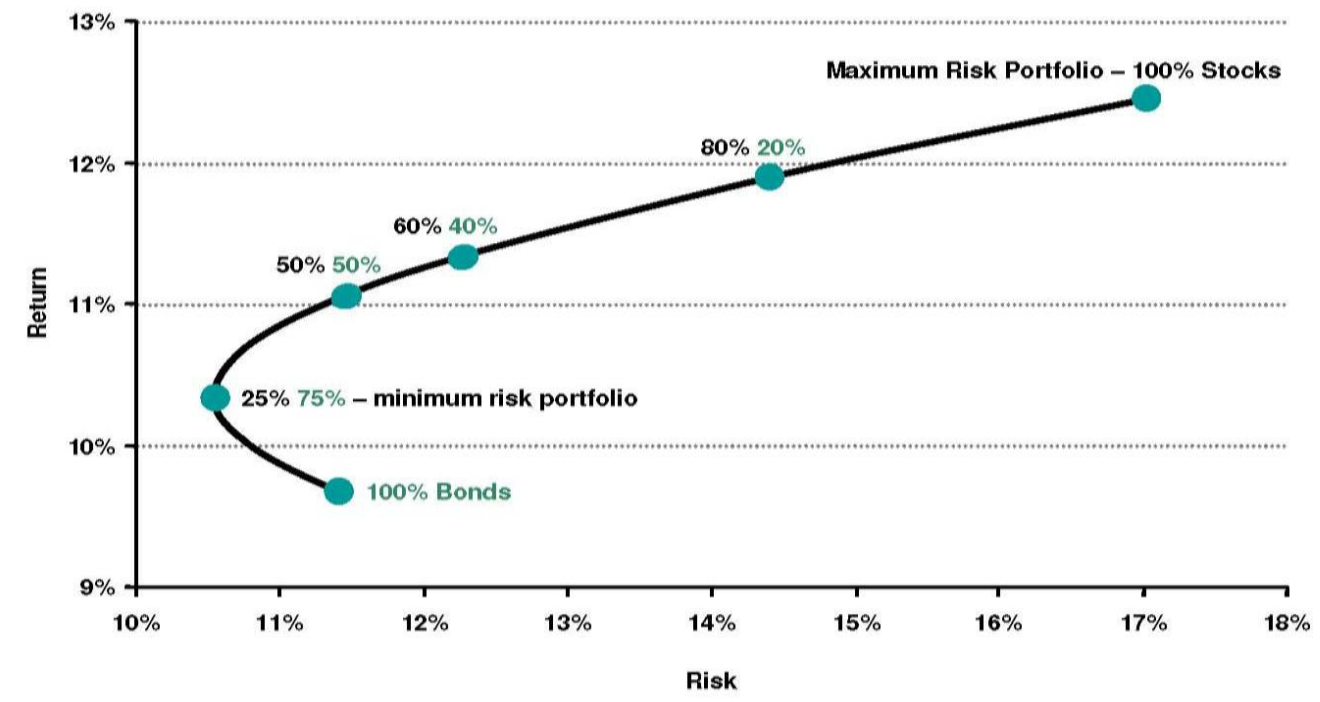

Risk is measured by standard deviation. Return is measured by arithmetic mean. Risk and return are based on annual data over the period 1970-2005. Portfolios presented are based on modern portfolio theory.

Figure 2: Investment Pyramid ${ }^{3}$

Balancing Risk E Reward

As you can see from the investment pyramid, risk varies among types of investments. Bank savings accounts, CDs and life insurance programs represent the foundation of your savings program and carry a low amount of risk, and consequently, provide a lower return on your investment. As you ascend the investment pyramid, stocks represent a higher degree risk because of the unpredictable forces that govern the rise and fall of the stock market namely, interest rates, world events, company and industry performance, and many more.

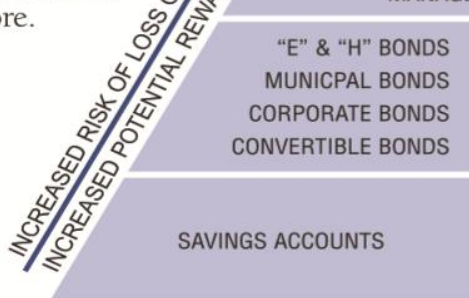

"E" \& "H" BONDS MUNICPAL BONDS CORPORATE BONDS CONVERTIBLE BONDS SAVINGS ACCOUNTS

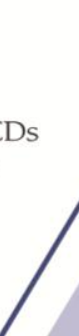

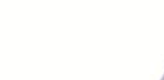

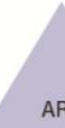

RARE COINS GOLD \& SILVER PRECIOUS STONES STRATEGIC METALS SPECIAL

SALE OF CALL OPTIONS (UNCOVERED) PURCHASE OF CALL AND PUT OPTIONS
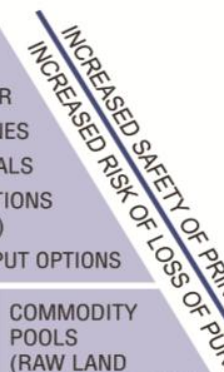

POOLS

CAPTIAL

(INCLUDING EXPLOR-

ATION

(FARM LAND, ETC.)

COMMERICAL \& RESIDENTIAL REAL ESTATE OBTAINED FOR INVESTMENT PURPOSES OIL AND GAS INCOME PROGRAMS MUTUAL FUNDS AGED ACCOUNTS

BLUE CHIP STOCKS

SALE OF CALL OPTIONS (COVERED)

FIXED ANNUITIES VARIABLE ANNUITIES INSURED MUNICIPALS TREASURY NOTES \& BILLS

LIFE INSURANCE

(CASH VALUES) RETIREMENT PROGRAMS 
The investment pyramid is another way to depict the risk/reward characteristics of investments in a portfolio (Figure 2). While the allocations change depending on the risk tolerance of the client, the premise behind the pyramid is that the base of all portfolios should begin with low risk investments and taper off in volume as risk increases. This strategy promotes diversification and fits in well with Markowitz's modern portfolio theory.

With an understanding of how portfolios are created, it is important to see how taxes affect performance and how to achieve tax efficiency. This becomes increasingly important based on the higher the client's marginal tax rate. To see how taxes will affect performance, subtract the tax liability from each investment. If investments are tax deferred or tax free you must find the tax equivalent yield. The formula for tax equivalent yield is as follows:

Tax Equivalent Yield $=$ Tax Free Yield $/$ 1-Marginal Tax Rate ${ }^{4}$

\section{TRADITIONAL USES OF LIFE INSURANCE}

The two major types of life insurance are term life and permanent life. Term life guarantees coverage for a specific period of time. Typical periods are 1-30 years or until a specific age, e.g. age 80. Term policies should be used to cover liabilities that are amortized or scheduled for retirement, such as a mortgage or a long term business loan. Permanent life insurance guarantees coverage until death as long as the premiums are paid and have a cash value. The cash value of a policy is the surrender value of the policy if terminated. These policies should be used to pay liabilities that do not have a time horizon such as estate taxes.

Figure 3: Types of Life Insurance ${ }^{5}$

\begin{tabular}{|c|c|c|c|}
\hline & Term Insurance & Permanent Insurance & Universal Insurance \\
\hline Overview & Temporary coverage. & $\begin{array}{l}\text { Lifetime coverage. Provides tax- } \\
\text { deferred savings. }\end{array}$ & $\begin{array}{l}\text { Lifetime coverage. Flexible } \\
\text { deposits that provide tax- } \\
\text { deferred savings. }\end{array}$ \\
\hline Coverage Length & $\begin{array}{l}\text { Coverage ends at a specified } \\
\text { age. }\end{array}$ & Lifetime protection. & Lifetime protection. \\
\hline Benefit Amount & $\begin{array}{l}\text { You choose the benefit amount } \\
\text { when you purchase the } \\
\text { insurance and it won't change. }\end{array}$ & $\begin{array}{l}\text { You choose the benefit amount, } \\
\text { with ability to increase coverage. }\end{array}$ & $\begin{array}{l}\text { You choose the benefit amount, } \\
\text { with ability to increase } \\
\text { coverage. }\end{array}$ \\
\hline Cost & $\begin{array}{l}\text { The lowest premiums when } \\
\text { purchased, but premiums will } \\
\text { increase over time and become } \\
\text { very expensive in your older } \\
\text { years. }\end{array}$ & $\begin{array}{l}\text { Some products have adjustable } \\
\text { premiums, and others have a } \\
\text { guaranteed premium. Premiums } \\
\text { may be higher when you're } \\
\text { young and then become lower as } \\
\text { you age. }\end{array}$ & $\begin{array}{l}\text { Premiums vary depending on } \\
\text { the policy. Some products have } \\
\text { level premiums, others have } \\
\text { premiums that increase. }\end{array}$ \\
\hline Cash Value & No cash value. & $\begin{array}{l}\text { A cash value may accumulate and } \\
\text { be paid to you upon cancellation } \\
\text { (depends on policy and } \\
\text { coverage). }\end{array}$ & $\begin{array}{l}\text { A cash value may accumulate } \\
\text { and be paid to you upon } \\
\text { cancellation (depends on policy } \\
\text { and coverage). }\end{array}$ \\
\hline
\end{tabular}

Permanent policies can further be classified into universal life, variable universal life, whole life, and participating whole life. Universal life is best described as a term policy with a high yield savings account component. The idea is that in the early premium years a portion of the premiums are used to pay for the term policy, while the remaining premiums go into the high yield savings account to supplement the increased cost of insurance in later years. The value of the high yield savings account is the cash value of the policy. Though usually less expensive, the shortfall to such insurance requires the insured to bare the risk if the high yield savings account has not grown sufficiently to pay the increased cost of insurance in the later years of life. Variable universal life works off the same premise except the additional premiums go into a variable stock portfolio of the owner's discretion instead of a savings account. Whole life policies have set premiums that guarantee coverage for life; this guarantee makes whole life generally more expensive than its universal life counterparts. Participating whole life policies are offered by mutual companies that are owned by their policy holders. This ownership entitles policy holders to a return of the insurer's profits in the form of dividends. These dividends can be used in many ways including the purchase of additional paid-up insurance, an increase in cash value, or taken out of the policy as cash (Figure 3). 
Before exploring where a risk protection product such as life insurance falls within the investment pyramid, let's review some of the common misconceptions of cash value or permanent life insurance. The first and greatest misconception is permanent life insurance is too expensive, and one would be better off buying term insurance and investing the rest in the stock market. ${ }^{6}$ Though term life insurance plays an important role in protecting assets for periods of time, this strategy fails as the primary objective of providing a death benefit. Research provided by the Life Insurance and Marketing Research Association (LIMRA) has shown that $99 \%$ of all retail term life policies expire unexercised. ${ }^{7}$ Given these facts, if the client's goal is to use life insurance as the most tax efficient way to move assets from one generation to another it's imperative to have a policy in force at the time of death. The argument behind buying term and investing the difference fails as an investment philosophy because very few people use the savings to invest in the market.

\section{BANK OWNED LIFE INSURANCE (BOLI)}

The investment properties of permanent life insurance have been capitalized on by the largest financial institutions in the world - the banks. Bank Owned Life Insurance (BOLI) is most commonly designed as a single premium life insurance contract. Banks take advantage of owning permanent life insurance for the tax-free income and as a way to circumvent some of the expenses of providing retirement benefits to highly compensated employees. ${ }^{8}$ According to the State of New York Banking Department, investment results under BOLI contemplate substantial tax benefits arising from interim deferral of taxes on investment income held within the policy and the absence of taxation upon payment of the death benefit. ${ }^{9}$

Traditional bank investments create taxable interest income, but BOLI doesn't result in current income tax liability because earnings are sheltered inside the life insurance contract. If the policy is held until death occurs, the bank will receive life insurance proceeds tax-free. By implementing a BOLI strategy, a bank can increase its returns by 100 to 350 basis points (Figure 4). ${ }^{10}$ Federal banking regulators declared that BOLI can provide attractive taxequivalent yields to help offset the rapidly rising cost of providing employee benefits in the OCC Bulletin 2004-56. ${ }^{8}$ Corporations have not missed out on participating in this unique investment and have their own version known as Corporate Owned Life Insurance (COLI). ${ }^{11}$

Figure 4: Increased Returns through BOLI ${ }^{12}$

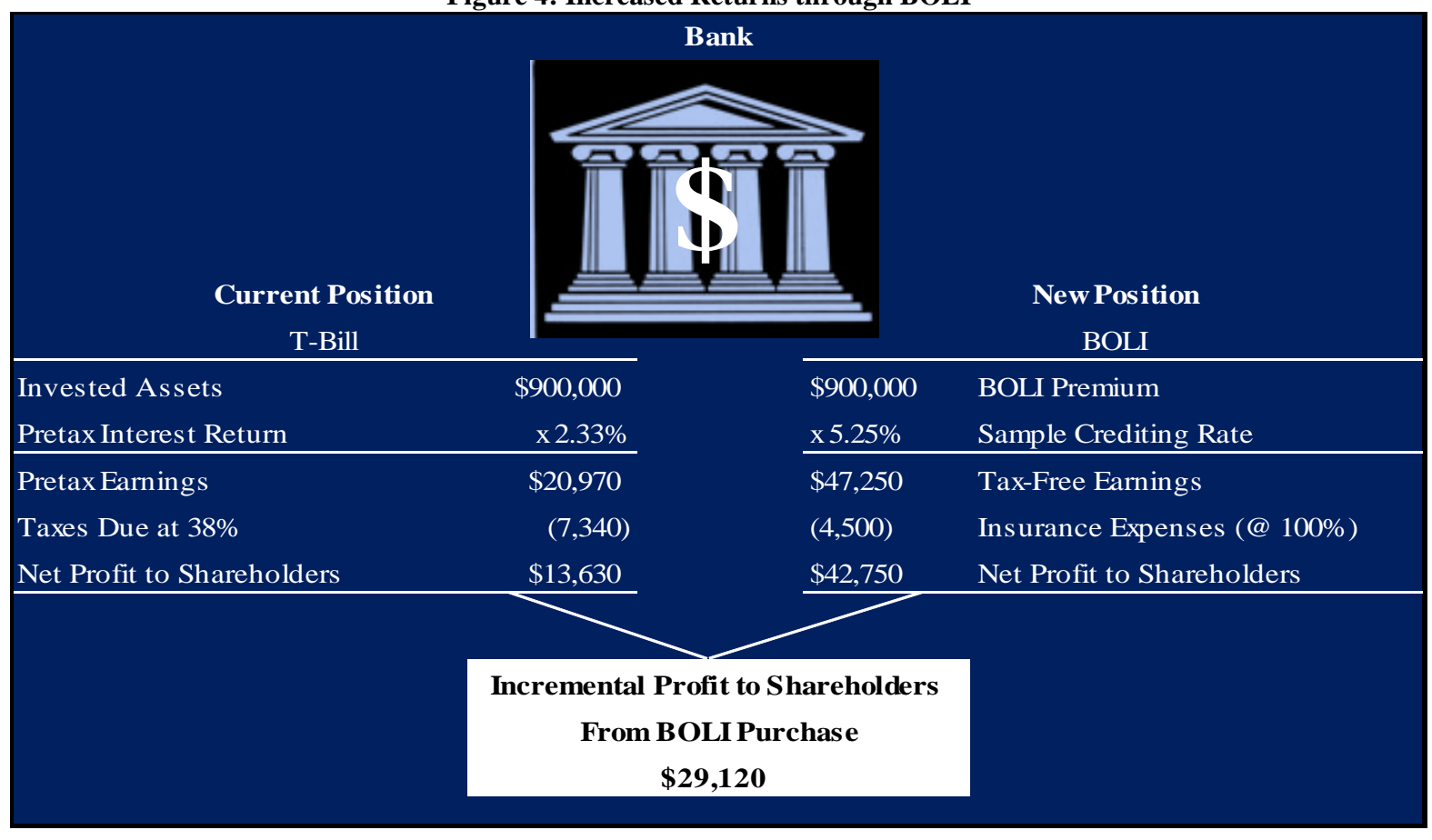




\section{LIFE INSURANCE RETIREMENT PLANS FOR INDIVIDUAL INVESTORS}

With the understanding of how banks and corporations have utilized life insurance to lower risk and increase returns, we begin to see how individuals can stabilize portfolios with life insurance. From the Investment Pyramid we saw that the lowest rung in the pyramid contains saving accounts, checking accounts, certificates of deposit (CDs), commercial paper, and cash value life insurance. All of these investments, except for CDs with maturities greater than a year and the cash value life insurance, are cash substitutes. Cash substitutes are at the bottom of the pyramid because they are liquid and are only subject to inflation risk. The CDs are not only less liquid but are subject to interest rate risk, inflation risk, and financial risk. The only choice on the bottom of the investment pyramid that offers any kind of tax shelter is permanent life insurance.

The tax deferral of life insurance helps ensure it against inflation risk, but it is subject to financial risk and interest rate risk indirectly. Besides the ability to outpace cash substitutes on yield with the added bonus of tax deferral, life insurance premiums and subsequent cash values are leveraged as insurance against premature death. This feature is less important to the investor with no dependents or likelihood for dependents, but is of imminent importance to the investor that has dependents and is still in pre-retirement age where there are also outstanding debts, mortgages, and obligations of raising a family.

Once the investor is in retirement he/she has the options of keeping the insurance policy in force for pure risk management purposes, terminating the policy and taking the cash value as a lump sum, taking the cash value in a subsequent series of equal cash payments with an annuitization option, or any combination of the three. It is important to recognize the dual effects of a plan like this, but this paper focuses on the investment and tax qualities of such a plan. Life insurance can help increase the yield of the lower part of your investment base while also decreasing risk and deferring all gains from taxes. Now that we have seen where plans like this fall into a portfolio and the unique characteristics that are associated with them, it is time to start looking at who would qualify or be best suited for these types of plans.

\section{INSURABILITY}

Besides people with high incomes that desire extra retirement income, participators of such plans must pass the insurability requirement of the insurer. This is the most precarious requirement of such a plan and is extremely important in determining the rate of return for these policies. Discounting the lack of education in products such as these, the insurability requirement is an entry level barrier too great for many advisors to contend with. Different insurers use different qualifications and scales, but they all attempt to measure the same thing - the cost of insurance. The cost of insurance is passed on to the insured and lowers the rate of return. These requirements narrow your clientele to high income earners that are in good health.

\section{A PRACTICAL EXAMPLE}

Let's look at a physician who owns his own firm and is making $\$ 375,000$ a year. The physician is 35 and is planning on retiring at age 55 , after the economic downturn he has $\$ 100,000$ in his $401 \mathrm{k}$. The investment returns in this scenario are going to be quite liberal in order to better illustrate the value of such a plan. In addition to the $\$ 100,000$ he has already accumulated we are going to assume that he contributes the maximum of $\$ 16,500$ per year without any additional catch-up contributions and earns an average $12 \%$ per year on everything in this account. Once in retirement our physician is going to reduce the risk in his account so that his average return over the next 30 years of payout is $6 \%$ annually. With these liberal return assumptions our physician will be able to receive an annual income of $\$ 156,449$ per year.

Growth Phase: Age 35-55

$\left(\$ 100,000(1.12)^{20}\right)+\left(16,500 \times\left(\left((1.12)^{20}-1\right) / .12\right)\right)=\$ 2,153,494$ available at age 55

Distribution Phase: Age 55-85

$\$ 2,153,494 /\left(\left(1-\left(1 /(1.06)^{30}\right)\right) / .06\right)=\$ 156,449$ per year 
Though these returns are exemplary, they are less than half of the physician's current income, assuming that his salary has no increases over the second half of his career. There are more sophisticated ways to determine income needed in retirement, but a good rule is to use $80 \%$ of pre-retirement income. Using his income at age 35 and assuming no increases in pay, his retirement income needs would be $\$ 300,000$ per year. The difference between his retirement needs and the stream of income his $401 \mathrm{k}$ would provide is roughly $\$ 143,551$. This shortfall could come from several different sources such as personal investment accounts, annuities, rental properties, real-estate sales, royalties, social security, and life insurance. Of these investments life insurance, annuities, and rental properties have the best qualities when it comes to tax deferral, but only annuities and life insurance can guarantee a future stream of income until death.

Let's now assume that our physician is concerned with the threat of owing estate taxes and how it could force his heirs to liquidate real property to pay taxes. He realizes that this assumption is based on several variables including but not limited to the rate that he consumes assets during retirement and changes in tax law that may decrease or increase the size of an estate before it becomes taxable. Now, he is faced with two major financial problems that seem to be mutually independent; the knowledge that his planning without any additions will leave him with a substantial income gap and a major change in lifestyle, and the fear that his estate may grow to the point of catabolism from the effects of estate taxes. These decisions don't only appear mutually exclusive, but inversely correlated. The cost of purchasing life insurance would be subtracted from his disposable income decreasing his ability to invest and fund his future retirement (Figure 6). This scenario plagues a large and ever growing portion of Americans approaching retirement. A solution that can protect estates and be available for retirement income is a LIRP.

Continuing with the example, the physician could purchase a participating whole policy for $\$ 1,000,000$. Assuming average health the price of most policies would range between $\$ 10,000$ and $\$ 15,000$ per year. Assuming that all dividends are reinvested, the policy would gain in cash value until death. It generally takes 10-15 years for a policy like this to breakeven. After breakeven, the policy would continue to grow at higher rates each subsequent year. After 20 years of ownership and age 55 when the physician plans to retire, a policy similar to this should be worth $\$ 300,000$ to $\$ 400,000$. Since the growth rate of return on investment (ROI) increases significantly over time and the leverage of the death benefit is so great the use of the cash value is always a last resort. After another 10 years or age 65 the cash value of such a policy would be over $\$ 1,000,000$. This constitutes a pre tax rate of return between $4 \%-5.5 \%$, and an after tax rate of 6.15\% - 8.46\% assuming a 35\% marginal tax bracket (Figure 5). Simultaneous to the increase of cash there is also an increase in death benefit so not to be outpaced by the cash value. In this case the LIRP does not only satisfy both financial issues with one funding source, but allows the insured numerous options on how to use the cash value and the death benefit - including lump sum distributions and/or annuitization.

Figure 5: Example of Benefits Using Figures from an Actual Ledger of a 35 Year Old (Company Undisclosed)

\begin{tabular}{|c|c|c|c|c|c|}
\hline Age & $\begin{array}{c}\text { Total Premium } \\
\text { Outlay }\end{array}$ & Death Benefit & $\begin{array}{c}\text { Lump Sum } \\
\text { Payout }\end{array}$ & $\begin{array}{c}\text { Rate of Return (35\% } \\
\text { Tax Bracket) }\end{array}$ & $\begin{array}{c}\text { Annuitization / Guaranteed } \\
\text { Yearly Income for 30 years }\end{array}$ \\
\hline $\mathbf{5 5}$ & $\$ 249,800$ & $\$ 1,208,583$ & $\$ 386,230$ & $6.73 \%$ & $\$ 28,059.19$ \\
\hline $\mathbf{6 0}$ & $\$ 312,250$ & $\$ 1,360,804$ & $\$ 860,290$ & $7.89 \%$ & $\$ 62,499.13$ \\
\hline $\mathbf{6 5}$ & $\$ 374,700$ & $\$ 1,557,440$ & $\$ 1,221,050$ & $8.19 \%$ & $\$ 88,707.95$ \\
\hline
\end{tabular}

\section{TAX BENEFITS}

Congress has deemed life insurance as beneficial and has granted it special tax treatment. Three major tax benefits of life insurance are tax deferred growth, tax favored withdrawals, and tax free death benefit. Tax deferred growth occurs when the premiums exceed the cost of insurance, and in the case of mutual companies when the policy returns profits of the insurance company to the insured in the form of policy dividends. Tax favored withdrawals occur when loans are extracted from the policy. Both loans and dividends are generally not taxable as long as they do not exceed the basis of the policy (§ 7702). Likewise, partial surrenders and surrenders of additions are generally not taxable until they exceed basis. However, partial surrenders during the first 15 years of a policy may result in taxation under the forced-out gain rule. Unless there is a transfer for consideration, the face value of 
the insurance minus any loans will pass directly to the beneficiaries' tax free $(\S 101){ }^{13}$ Two of the greatest pitfalls of LIRPs are the re-characterization of the life insurance contract to a modified endowment contract (MEC) and what is known as a surrender squeeze.

Figure 6: Flow of Monies

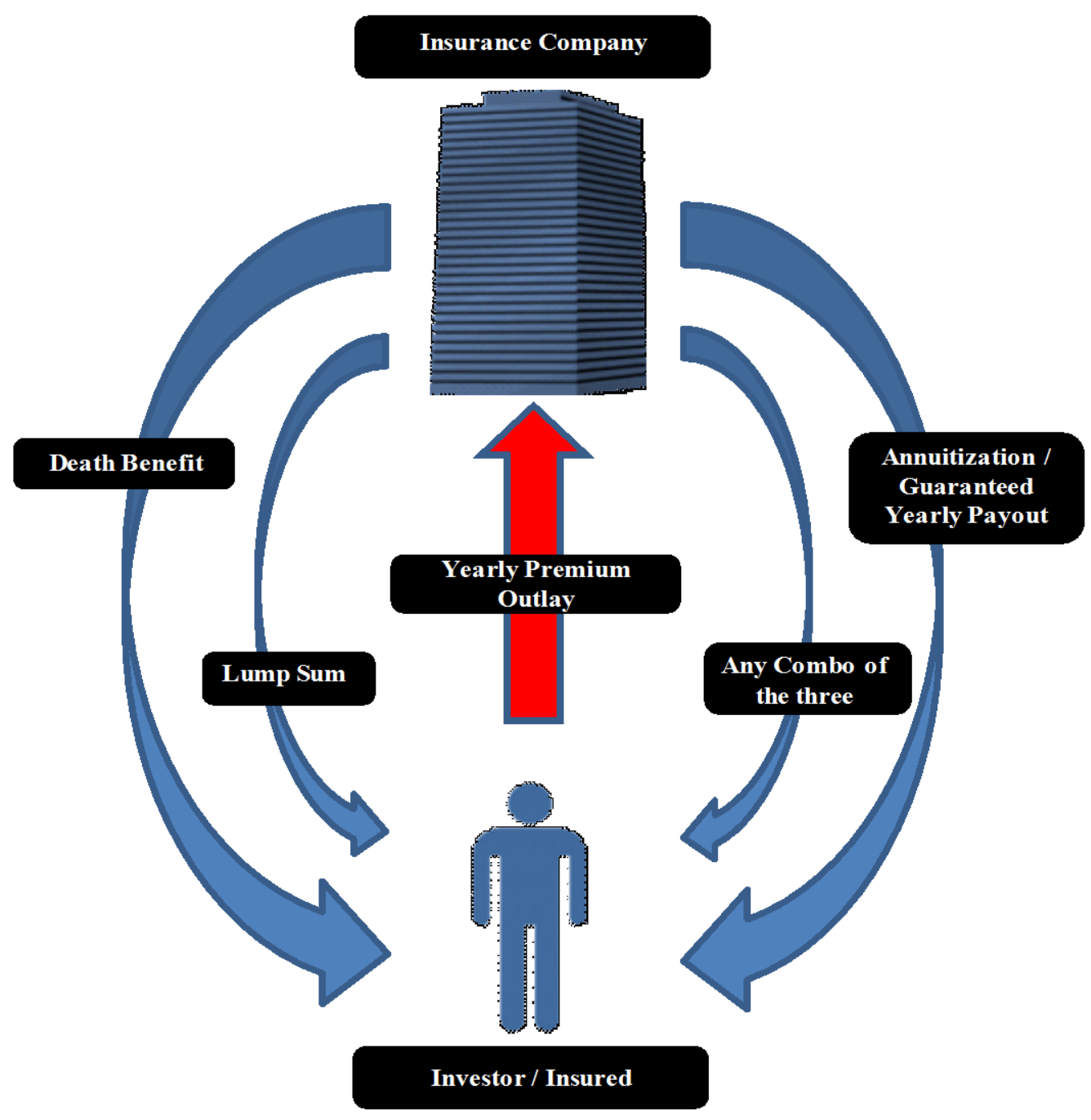

\section{MODIFIED ENDOWMENT CONTRACTS (MEC)}

Modified Endowment Contract is a term the IRS gives to certain cash value policies that have been deemed an inappropriate use of life insurance for death benefit purposes. MEC status basically changes the laws regarding the life insurance contract to mirror the tax laws governing annuities. The IRS has determined that any permanent policy that fails a seven pay-test described in IRS Code $\S 7702 \mathrm{~A}$ falls into MEC status. The seven pay-test sets a limitation on the total amount you can pay into your policy in the first seven years of its existence. The test is designed to discourage premium schedules that would result in a paid-up policy before the end of a seven-year period. Congress has determined that MECs must form a special category of life insurance and be subject to special rules of taxation. MECs are still life insurance, but Congress considers them to be a close relative to investments 
because of the emphasis on tax-deferred buildup of cash values. If cash values accumulate too fast in a life insurance policy, it might be considered more of an investment vehicle than protection against premature death. Therefore, MECs enjoy some but not all of the tax advantages of regular life insurance policies. The major drawback to a MEC is the $10 \%$ federal penalty for early withdrawal prior to age $591 / 2$ and the fact that distributions are taxed as coming from earnings first. Any surrender from a MEC is subject to income taxation on gain in the policy (and possible penalty). A loan or distribution from a MEC causes ordinary income tax to the extent of any gain in the policy, plus a $10 \%$ penalty unless the policy owner is age $59 \mathrm{1} / 2$, disabled, or takes substantially equal periodic payments over their life expectancy $(\S 72 \mathrm{t}$ ). A pledge or assignment of a MEC also triggers taxation (and possible penalty). The complete surrender or lapse of a policy causes taxation on any gain in the policy. The differences between MEC and non-MEC contracts are illustrated below (Figure 7$){ }^{14}$

Figure 7: Comparison of Income Tax Treatment - Non MEC vs. MEC ${ }^{15}$

\begin{tabular}{|c|c|c|}
\hline - & Non-MEC & MEC \\
\hline Loan (or assignment) & Not taxable & Taxable* \\
\hline Cash dividend & Tax free until basis recovered & Taxable* \\
\hline Partial surrender & Tax free until basis recovered & Taxable* \\
\hline Dividend to pay premiums & Not taxable & Not taxable \\
\hline Loan to pay premium & Not taxable & Taxable* \\
\hline Use of dividend and/or paid-up dividend additions to pay premium & Not taxable & Not taxable \\
\hline Death Benefit & Not taxable & Not taxable \\
\hline
\end{tabular}

\section{SURRENDER SQUEEZE}

The second major pitfall to LIRPs is the threat of a surrender squeeze. A "surrender squeeze" occurs when a heavily loaned policy is surrendered and the income tax due exceeds the cash value of the policy. ${ }^{15}$ A surrender squeeze is easily avoided by not taking large loans out against the policy in its infant years. LIRPs falling into MEC status and being forced out through a "surrender squeeze" are easily avoided and fall within the responsibilities of the advisor.

\section{CONCLUSION}

The investment qualities of life insurance are undeniable and can help some high net worth individual investors in creating a future stream of income with a tax favorable benefit in the form of a private pension. These facts notwithstanding, the sales practices of life insurance as a retirement vehicle has gained the attention of the NASD. In 2004, Northwestern Mutual Investment Services and the NASD reached a settlement agreement after being investigated since 2001 for emphasizing the investment qualities of life insurance while not properly stressing the risk of the policy being classified as a Modified Endowment Contract or the risk of a surrender squeeze. The investigation focused on Tom Lipscomb's unusual success in the personal insurance market and his remarks as a key speaker at many corporate functions. Though publicly declaring that Lipscomb did not harm any of his clients he was fined \$250,000. ${ }^{16}$ The NASD acknowledges the investment qualities of insurance, but believes that these qualities should be expressed secondary to their traditional purpose of risk management. This ruling has not only discouraged advisors from talking about LIRPs, but has also placed an undeserving taboo on such plans. This new sentiment concerning LIRPs and private pensions is unfortunate given the current position of Social Security and the possible failure of so many corporate pension plans. Given the unique qualities of LIRPs in providing a tax favored future stream of income that cannot be outlived, LIRPs can be used to supplement corporate and government pensions that are in doubt.

\section{AUTHOR INFORMATION}

Johnny Fryar, Jr. is a 2002 graduate of The Citadel and is a financial advisor in Myrtle Beach, South Carolina. He is currently taking accounting courses at Coastal Carolina University as a pre-requisite to a MBA in accounting. He can be reached at JohnnyFryar@ hotmail.com. 


\section{REFERENCES}

1. Markowitz, H. M. (1952). Portfolio Selection. Journal of Finance, 77-91.

2. Investment Methodology: Diversification, a Free Lunch. (n.d.). Retrieved June 7, 2009, from Capital at Work: http://www.capitalatwork.com

3. Products \& Services: Investment Pyramid. (n.d.). Retrieved April 10, 2009, from Lincoln Investment: http://www.lincolninvestment.com

4. $\quad$ Bruce, L. (n.d.). CDs \& Investments: Tax-Equivalent Yield Formula. Retrieved June 4, 2009, from Bank Rate: http://www.bankrate.com

5. Staples, E. (n.d.). Life Insurance: Types of Life Insurance. Retrieved September 22, 2009, from The Staples Financial Group: http://staplesfinancialgroup.com

6. Why You Should Never Buy Whole Life Insurance. (2007, August 24). Retrieved October 11, 2009, from Building Wealth - Cutting Costs: http://cutthatbill.com

7. Baldwin, B. G. (1994). New Life Insurance Investment Advisor. New York: McGraw-Hill.

8. Interagency Statement on the Purchase and Risk Management of Life Insurance, OCC 2004-56. (2004, December 4). Retrieved 15 2009, May, from Comptroller of the Currency, Administrator of National Banks, U.S. Department of the Treasury: http://www.occ.treas.gov

9. McCaul, E. (2006, January 3). Guidance on Bank Owned Life Insurance (BOLI) Programs. Retrieved November 12, 2009, from State of New York Banking Department: http://www.banking.state.ny.us

10. Resource Center: Bank-Owned Life Insurance (BOLI). (n.d.). Retrieved 28 2009, April, from New York Life Insurance Company: http://www.newyorklife.com

11. Schnurr, R. (2008, July). A Layman's Guide to Corporate-Owned Life Insurance. Retrieved August 12, 2009, from Society of Actuaries: http://www.soa.org

12. BOLI. (n.d.). Retrieved May 11, 2009, from Evergreen Consulting, Inc.: http://www.evergreenci.com

13. Stevick, G. E. (2007, July). Life Insurance: The Income-Tax Treatment of Life Insurance. Retrieved October 11, 2009, from Advisor Today: http://www.advisortoday.com

14. What is a Modified Endowment Contract (MEC)? (2008, August 1). Retrieved 14 2009, July, from United Services Automobile Association : https://www.usaa.com

15. Income Tax Basics of Life Insurance. (2008). Retrieved May 4, 2009, from Insure Your Health Now: http://www.insureyourhealthnow.com

16. Northwestern Mutual Investment Services Announces Resolution with NASD. (2004, November 14). Retrieved April 11, 2009, from Northwestern Mutual Financial Network: http://northwesternmutual.mediaroom.com 


\section{NOTES}

